\title{
Electrochemical studies of $p$-sulfonatocalix[4]arene in ionic liquid as supporting electrolyte
}

\author{
Ninie Suhana Abdul Manan ${ }^{a}$, Chris Hardacre ${ }^{b}$, Wan Jeffrey Basirun ${ }^{a}$ and Yatimah \\ Alias $^{\text {a* }}$ \\ ${ }^{a}$ Department of Chemistry, Faculty of Science, University of Malaya, 50603 Kuala Lumpur, Malaysia \\ ${ }^{b}$ School of Chemistry and Chemical Engineering, Queen's University Belfast, University Road, Belfast, BT7 \\ $1 \mathrm{NN}$, Northern Ireland, UK \\ * yatimah70@um.edu.my (Corresponding author).
}

Received on $18^{\text {th }}$ August 2009, accepted in revised form $13^{\text {th }}$ July 2010.

\begin{abstract}
The electrochemical behaviour of sodium $p$-sulfonatocalix[4]arene (s- $\left.p \mathrm{sc}_{4}\right)$ was studied. In this study ionic liquid/water mixtures were used as electrolyte, namely, $[\mathrm{BMIM}]\left[\mathrm{BF}_{4}\right] /$ water mixture and $[\mathrm{BMIM}][\mathrm{OTf}] /$ water mixture $\left([\mathrm{BMIM}]=1\right.$-butyl 3-methyl imidazolium, $\mathrm{BF}_{4}=$ tetrafluoroborate, $\mathrm{OTf}=$ trifluoromethanesulfonate). S- $p \mathrm{sc}_{4}$ can be oxidised at $0.84 \mathrm{~V}$ and $0.83 \mathrm{~V}$ in $[\mathrm{BMIM}]\left[\mathrm{BF}_{4}\right] /$ water and $[\mathrm{BMIM}][\mathrm{OTf}] /$ water respectively. The reaction is an irreversible process for both systems. The number of electron transferred in this electrochemical process is one electron and the diffusion coefficient, $(D)$ for both systems was $1.15 \times 10^{-8} \mathrm{~cm}^{2} \mathrm{~s}^{-1}$ and $1.67 \times 10^{-8} \mathrm{~cm}^{2} \mathrm{~s}^{-1}$ respectively. The anodic potentials were affected by temperature and the activation energy, $\left(E_{\mathrm{d}}\right)$ was $18.18 \mathrm{~kJ} \mathrm{~mol}^{-1}$ and $18.78 \mathrm{~kJ} \mathrm{~mol}^{-1}$ in $[\mathrm{BMIM}]\left[\mathrm{BF}_{4}\right] /$ water mixture and [BMIM][OTf]/water mixture respectively.
\end{abstract}

\section{INTRODUCTION}

Sodium $p$-sulfonatocalix[4]arene is a watersoluble electroactive species. The unique arrangement of sodium $p$-sulfonatocalix[4]arene and the ability to do a self-assembly chemistry with other metals had attracted researchers to study and understand the behaviour and characteristic of calixarene in different conditions and structural modifications.

The electrochemical study of calixarene particularly sulfonated calixarene has been undertaken previously in aqueous solution and organic solvent ${ }^{1,2,3,4}$. The important of understanding the electrochemical behaviour of the inclusion compounds formed by sodium $p$ sulfonatocalix[4]arene has lead to the study on the electrochemical characteristics of the supramolecule itself. Ionic liquid is widely study as a replacement of the organic and aqueous solutions in the electrochemistry field.

The small electrochemical window provided by the aqueous solution and organic solvent has limited the full picture of the species formed. Moreover, the study in aqueous solution is always complicated by the presence of the hydrogen ${ }^{5}$ and the study at high temperature is very limited in organic solvent. Ionic liquid essentially composed of ions and therefore can stabilised unusual species which cannot be observed in molecular solvent or aqueous solution. It has wide electrochemical window to study full picture of the species formed in the solution and has high thermal stability. $[\mathrm{BMIM}]\left[\mathrm{BF}_{4}\right]$ and $[\mathrm{BMM}][\mathrm{OTf}]$ were used in this study as these two common ionic liquids soluble in water and it is interesting to understand the behaviour observed and the effect of the anions.

Therefore this work specifically carried out and focused on the electrochemical behaviour of the sodium $p$-sulfonatocalix[4]arene and $\left(\mathrm{N}_{1444}\right) \mathrm{SO}_{3}$ calix[4] arene using [BMIM] $\left[\mathrm{BF}_{4}\right]$ and [BMIM][OTf] as electrolyte.

\section{Experimental}

$0.01 \mathrm{~g}$ of s-psc $\mathrm{s}_{4}$ was dissolved in $1 \mathrm{ml}$ of $\mathrm{H}_{2} \mathrm{O}$. To the solution $1 \mathrm{ml}$ of ionic liquid was added. The mixture was stirred at room temperature until a homogeneous solution formed. The sample was deoxygenated by bubbling in nitrogen gas for 5 to 10 minutes prior to perform the electrochemical measurements. All the samples are treated in the same way. For the temperature dependence study, the temperature was control using thermo couple and oil bath was used to get a consistent heating.

The electrochemical experiments were carried out in an AUTOLAB (PGSTAT12/30/302) with a three-electrode cell. A glassy carbon disc electrode (diameter: $3 \mathrm{~mm}$ ) was used as working 
electrode. Platinum wire was used as the counter electrode.

The reference electrode was an IL reference electrode. The glassy carbon working electrode was polished to a mirror with diamond slurry and rinsed with acetone before use. Then, the ionic liquids ([BMIM] $\left[\mathrm{BF}_{4}\right]$ and [BMIM][OTf]) were scan at glassy carbon between $-3 \mathrm{~V}$ and $3 \mathrm{~V}$ (versus ILRE) respectively.

\section{RESULTS AND DISCUSSION}

Electrochemical behaviour of sodium $p$ sulfonatocalix[4]arene (s-psc $)$

The cyclic voltammogram of a solution containing $0.12 \quad \mathrm{M}$ of $\mathrm{s}^{-}-\mathrm{sc}_{4} \quad$ in $[\mathrm{BMIM}]\left[\mathrm{BF}_{4}\right] /$ water mixture by using $\mathrm{GC}$ as WE and SCE as RE at $100 \mathrm{mV} / \mathrm{s}$ is shown in Figure 1 (a). There is one oxidation peak observed at 0.84 $\mathrm{V}$ and no cathodic peak was detected at the reversed scan. When the scans were repeated for few cycles, the current was decrease to a steady value, zero.

This behaviour was expected where the electroactive species undergoing oxidation was depleted in concentration at the electrode surface and indicated that the electrochemical reaction was passivating the working electrode ${ }^{3}$. Therefore, the surface of working electrode was polished for every single scan.

The same behaviour of $s-p \mathrm{sc}_{4}$ was observed in [BMIM][OTf]/water mixture as one oxidation peak observed at $0.83 \mathrm{~V}$ and no cathodic peak detected on reversed scan (Figure (b)). Therefore the same explanation was suggested for $s-p s c_{4}$ in different electrolyte system of [BMIM][OTf]/water.

The oxidation peak observed was attributed to the oxidation on the GC surface ${ }^{3}$, which is well known and leads to the introduction of oxygen functionality to the surface and often used for the activation of such electrodes prior to electroanalysis. It has been shown that sodium $p$ sulfonatocalix[4]arene solutions can give rise one oxidation peak corresponding to the phenol ${ }^{6}$. Therefore, the peak was assigned to the oxidation of phenolic unit of the calixarene.

Such electrochemical oxidation are produced by para coupling of the phenolate radicals generated at the electrode surface leading to the deposition of polyphenol or polyphenylene oxide on the electrode $^{7}$. Scheme 1 shows the proposed electrochemical oxidation reaction of $\mathrm{s}^{-} \mathrm{psc}_{4}$ in ionic liquid/water mixture.<smiles>CC(C)(C)Cc1cc(O)cc(C(C)(C)C)c1S(=O)(=O)O</smiles><smiles>CCC(C)(C)c1cc([O-])cc(C(C)(C)C)c1S(=O)(=O)O</smiles><smiles>CC(C)(C)c1cc(O)cc(C(C)(C)C)c1S(=O)(=O)O</smiles>

Scheme 1: Proposed electrochemical oxidation of s- $p \mathrm{sc}_{4}$ in $[\mathrm{BMIM}]\left[\mathrm{BF}_{4}\right] /$ water and $[\mathrm{BMIM}][\mathrm{OTf}] /$ water. 
Number of electron ( $n$ ) and diffusion coefficient (D)

In order to investigate the behaviour of $s-p \mathrm{sc}_{4}$ in IL/water mixture further, the scan rate dependent studies were done. When the potential scan rate ranged from $10 \mathrm{mV} / \mathrm{s}$ to $400 \mathrm{mV} / \mathrm{s}$, both anodic peak potential, $E_{\mathrm{p}}$ and peak current, $I_{\mathrm{p}}$ are affected by scan rate as shown in Figure 1 (a) and (b). As the scan rate increase, the peak currents increase and the potential shifted to more positive potential.

According to Nicholson for an irreversible anodic reaction, the relationship between $\mathrm{E}_{p}$ and $v$ is

$$
\begin{array}{cc}
E_{\mathrm{p}}=E^{\circ}+\left(R T / \alpha n_{a} F\right) & {\left[0.780+\ln \left(D^{1 / 2} / k^{\circ}\right)+\ln \right.} \\
\left.\left(\alpha n_{a} F \vee / R T\right)^{1 / 2}\right] & \text { Equation } 1
\end{array}
$$

By plotting $E_{\mathrm{p}}$ versus $\ln v$ (Figure 2 (a) and (b)), the plot show a linear graph for $s-p \mathrm{sc}_{4}$ in both $[\mathrm{BMIM}]\left[\mathrm{BF}_{4}\right]$ and $[\mathrm{BMIM}][\mathrm{OTf}]$ in water mixture. This behaviour obeys the Nicholson's equation and confirmed that the electrochemical oxidation of $s-p \mathrm{sc}_{4}$ in ILs/water mixture in this experimental condition is totally irreversible.

According to the slope of the straight line of $E_{\mathrm{p}}$ against $\ln v$ the product of $\alpha n_{\mathrm{a}}$ can be evaluated. Plot $E_{\mathrm{p}}$ versus $\ln v$ (a) show the slope is $1.3 \times 10^{-3}$ while (b) show the slope is $1.1 \times 10^{-3}$. After simplifying the equation, the slope is $R T / 2 \alpha n_{a} F$. Therefore, the value of $\alpha n_{\mathrm{a}}$ is 0.99 in $[\mathrm{BMIM}]\left[\mathrm{BF}_{4}\right] /$ water mixture and 1.17 in [BMIM][OTf]/water mixture.
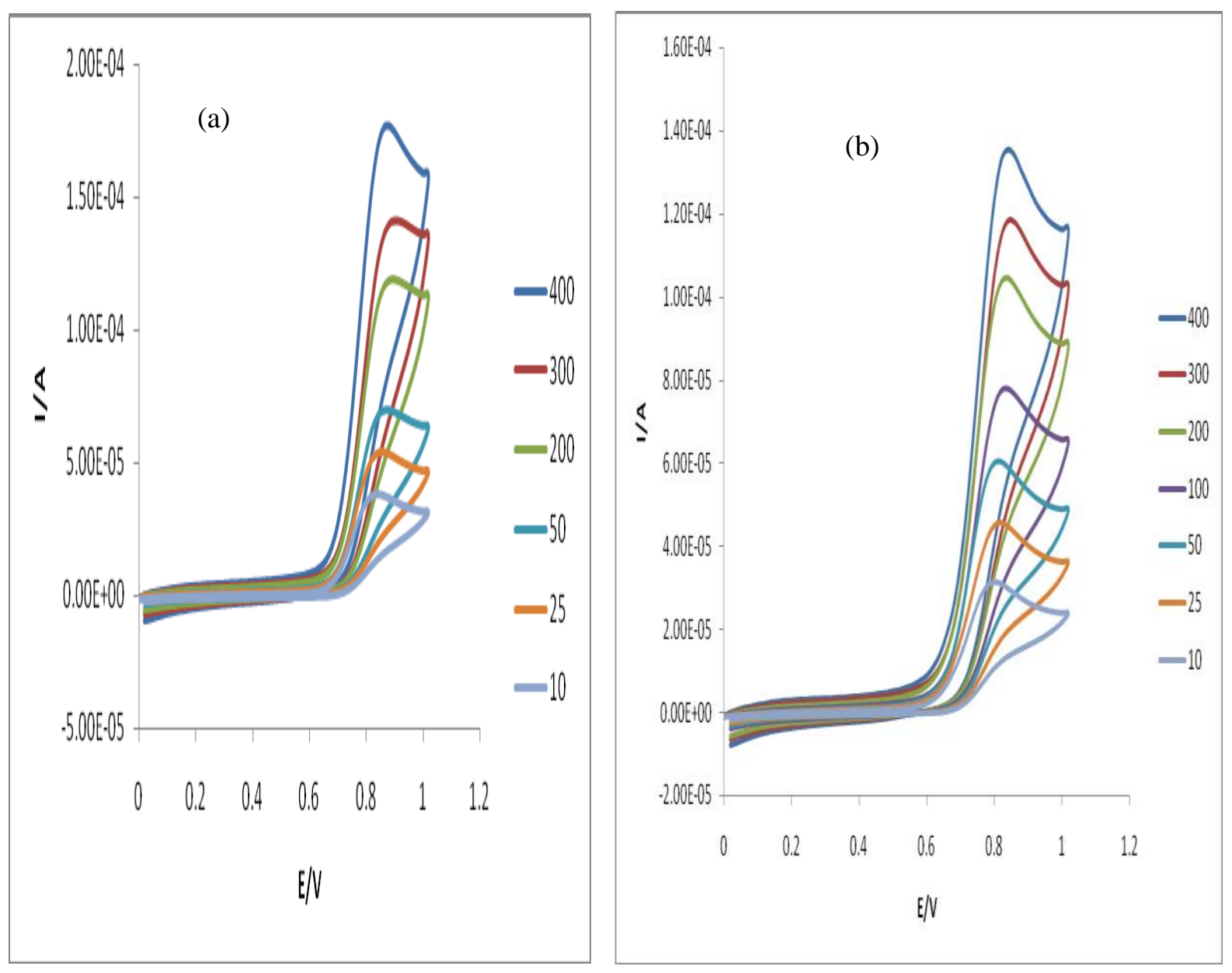

Figure 1: At $25^{\circ} \mathrm{C}$, the voltammogram of $0.12 \mathrm{M}$ of $s-p \mathrm{sc}_{4}$ in (a) $[\mathrm{BMIM}]\left[\mathrm{BF}_{4}\right] /$ water mixture and (b) [BMIM][OTf]/water mixture at scan rate ranged from $10 \mathrm{mV} / \mathrm{s}$ to $400 \mathrm{mV} / \mathrm{s}$, GC versus SCE. 

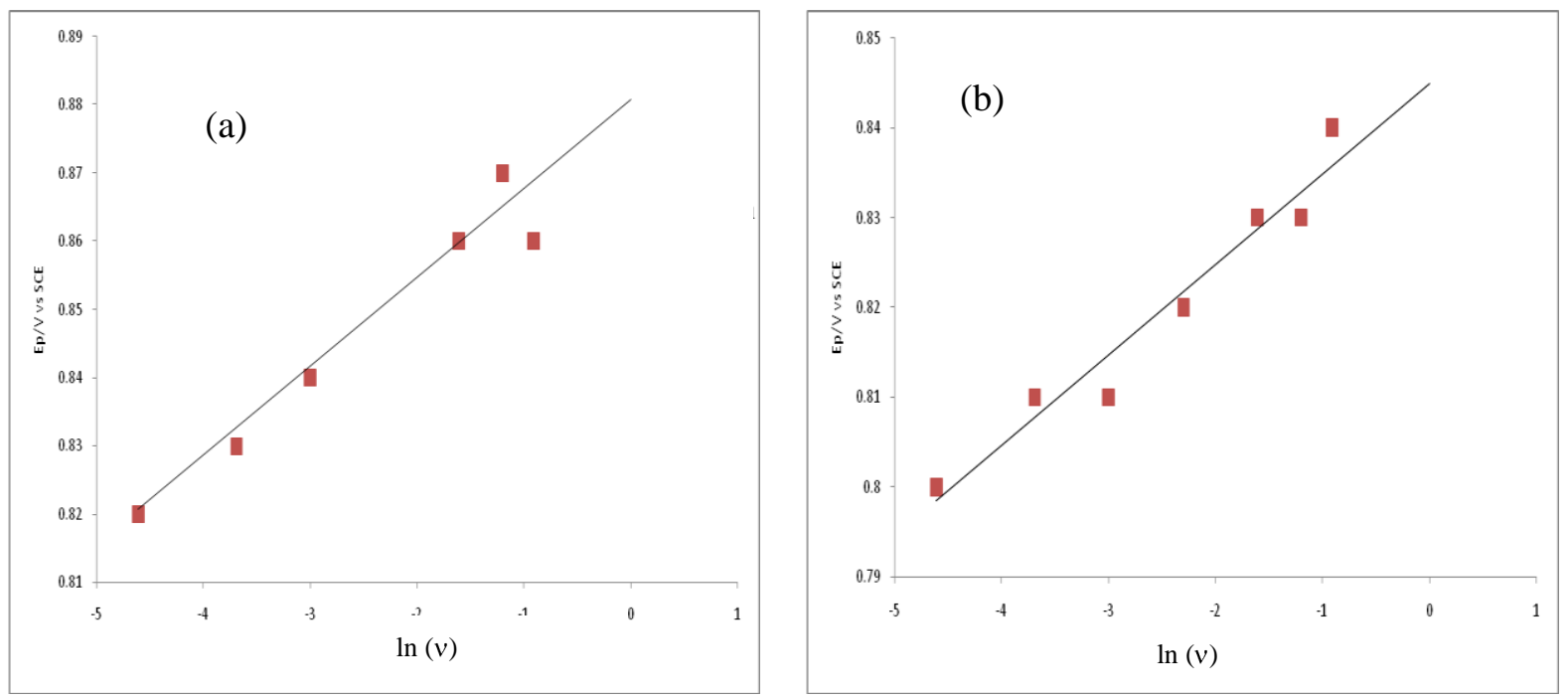

Figure 2: At $25^{\circ} \mathrm{C}$, the plot of $E_{p}$ versus $\ln (v)$ of $0.12 \mathrm{M}$ of s-psc$c_{4}$ in (a) $[\mathrm{BMIM}]\left[\mathrm{BF}_{4}\right] /$ water mixture and

(b) $[\mathrm{BMIM}][\mathrm{OTf}] /$ water mixture.

In addition, the peak current $I_{\mathrm{p}}$ for an irreversible electrochemical reaction can be described by the following formula

$$
I_{\mathrm{p}}=\left(2.99 \times 10^{5}\right) n\left(\alpha n_{a}\right)^{1 / 2} A \mathrm{C}^{*}{ }_{\mathrm{R}} D^{1 / 2} v^{1 / 2} \quad \ln (v)
$$

\section{Equation}

2

According to Equation 2, at a given concentration of $\mathrm{s}-p \mathrm{sc}_{4}$, the plot of peak current, $I_{\mathrm{p}}$ versus square root of the scan, $v^{1 / 2}$ should be linear

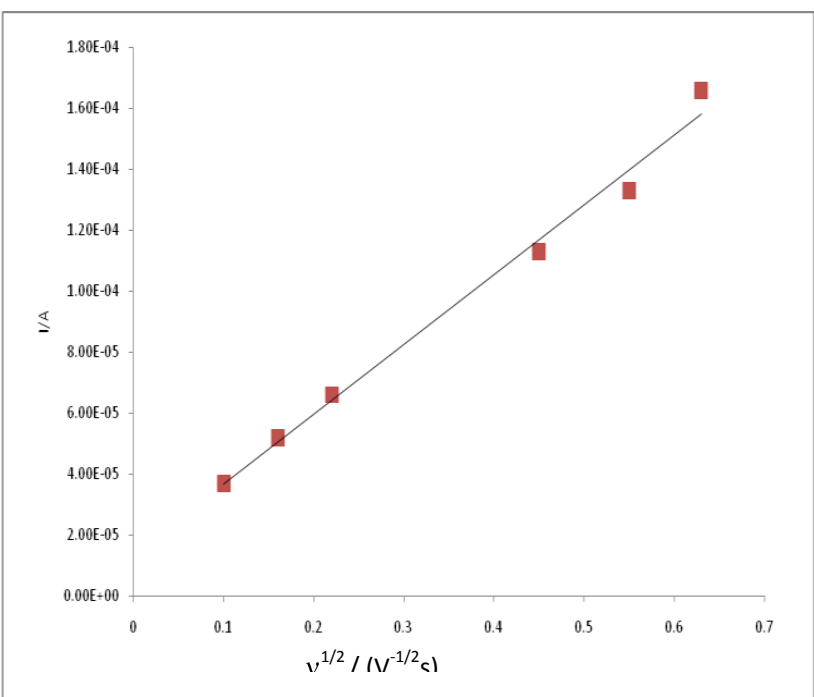

Figure 3; Plot of $I_{p}$ versus $v^{1 / 2}$ for (a) $s-p s c_{4}$ in [BMIM][OTf]/water mixture. passing through the origin. From the slope of the straight line, the value of $\left[n\left(\alpha n_{a}\right)^{1 / 2} A C^{*}{ }_{\mathrm{R}} D^{1 / 2}\right]$ can be evaluated (Figures 3 (a) and (b)). Linear plots of $I_{\mathrm{p}}$ versus $v^{1 / 2}$ was obtained and the parameter of $\left[n\left(\alpha n_{a}\right)^{1 / 2} D^{1 / 2}\right]$ was calculated as $9.03 \times 10^{-5}$ $\mathrm{cms}^{-1}$ for $[\mathrm{BMIM}]\left[\mathrm{BF}_{4}\right]$ and $6.99 \times 10^{-5} \mathrm{cms}^{-1}$ for [BMIM][OTf].

Combining the two parameters of $\alpha n_{\mathrm{a}}$ and $\left[n\left(\alpha n_{a}\right)^{1 / 2} D^{1 / 2}\right]$, the value of $n D^{1 / 2}$ can be evaluated as $9.07 \times 10^{5} \mathrm{cms}^{-1 / 2}$ and $6.46 \times 10^{-5} \mathrm{cms}^{-1 / 2}$ in $[\mathrm{BMIM}]\left[\mathrm{BF}_{4}\right] /$ water and [BMIM] $[\mathrm{OTf}] /$ water respectively .

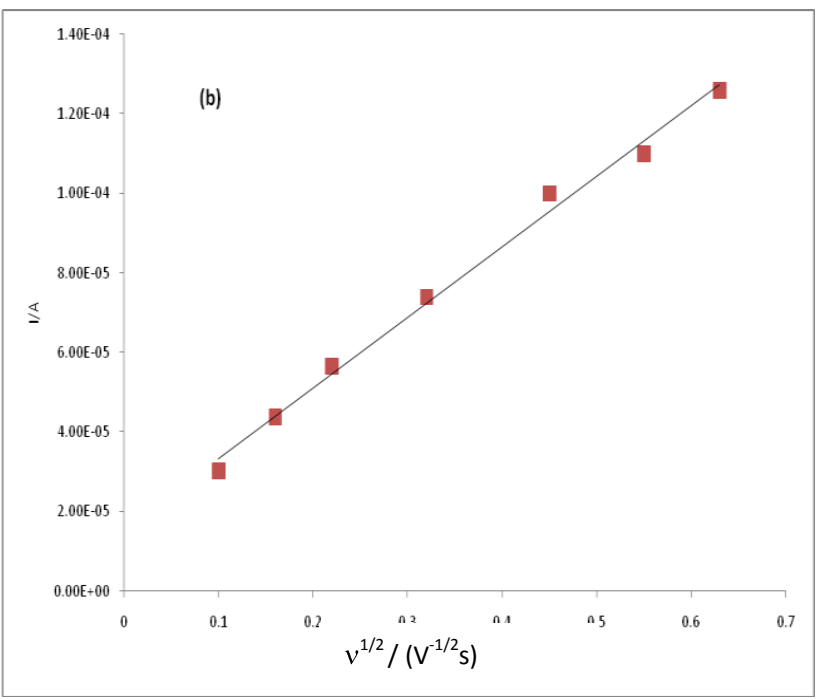


To get the value of $n$ and $D$, a steady voltammetry of $0.1 \quad \mathrm{M}$ of $\mathrm{s}_{-} p \mathrm{sc}_{4}$ in $[\mathrm{BMIM}]\left[\mathrm{BF}_{4}\right] /$ water and [BMIM] [OTf]/water on the same electrode was determined. The limitation diffusion current, $I_{1}$ is $8.38 \times 10^{-11} \mathrm{~A}$ and $5.80 \times 10^{-11} \mathrm{~A}$ respectively. Therefore the value of $n D$ can be calculated as $1.20 \times 10^{-8} \mathrm{~cm}^{2} \mathrm{~s}^{-}$ ${ }^{1}$ in $[\mathrm{BMIM}]\left[\mathrm{BF}_{4}\right] /$ water mixture and $8.35 \times 10^{-9}$ $\mathrm{cm}^{2} \mathrm{~s}^{-1}$ in [BMIM][OTf]/water mixture by using the following formula;

$I_{1}=4 n F D C^{*} r$

Equation 3

Combining with the value of $n D^{1 / 2}$ as described previously, the value of $D$ is calculated as $1.15 \mathrm{x}$ $10^{-8} \mathrm{~cm}^{2} \mathrm{~s}^{-1}$ and $1.67 \times 10^{-8} \mathrm{~cm}^{2} \mathrm{~s}^{-1}$ and the value of $n$ is calculated as 0.83 and 0.71 respectively. Taking account the error of calculation, it was assuming that the number of electron transfer for $s-p \mathrm{sc}_{4}$ in both IL/water mixture is 1 . Assuming $n_{\mathrm{a}}=n$, therefore the value of $\alpha$ is 0.99 (in $[\mathrm{BMIM}]\left[\mathrm{BF}_{4}\right] /$ water) and 1.17 (in [BMIM][OTf]/water). The value of the diffusion coefficient is small compared to the behaviour in other solvent ${ }^{1,2}$ as the ionic liquid has higher viscosity.

\section{Temperature dependence}

As shown in Figure 5 (a) and (b), both peak current and peak potential for the electrochemical reaction of $s-p \mathrm{sc}_{4}$ were affected by temperature. The anodic peak current increased with temperature. The peak potential shifted in negative direction with the temperature increasing, which tells us that it is easier for the oxidation of $s-p \mathrm{sc}_{4}$ at high temperature. This behaviour is due to the viscosity of the ionic liquid. At higher temperature the viscosity of IL will slightly decrease in viscosity ${ }^{8}$. Therefore, it was assumed that the movement of electroactive species of $s-p \mathrm{sc}_{4}$ in the solution easier at higher temperature. Taking account of $n_{a}, \alpha$ as independent of $T$, then according to Nicholson, the peak current, $I_{\mathrm{p}}$ at different temperature should be described as follows;

$$
I_{\mathrm{p}}=-04985 n F A\left(\alpha n_{a} F / R T\right)^{1 / 2} C^{*}{ }_{\mathrm{R}} D^{1 / 2} v^{1 / 2}
$$

Equation 4

From Equation 4, the diffusion coefficient, $D$ for different temperature can be calculated and the relationship between $D$ and temperature is

\section{Equation 5}

$$
\log D=-E_{d} /(2.303 R T)+\log D_{0}
$$

$E_{d}$ is the active energy of diffusion of s- $p \mathrm{sc}_{4}$. By plotting $\log D$ over $1 / T$ (Figure 6) the active energy diffusion of $s-p \mathrm{sc}_{4}$ can be evaluated as $18.41 \mathrm{~kJ} \mathrm{~mol}^{-1}$ in [BMIM][BF4]/water and 17.97 $\mathrm{kJ} \mathrm{mol}^{-1}$ in [BMIM][OTf]/water .By comparing the value of activation energy with reported in the literature ${ }^{2,4,6}, 29.00 \mathrm{~kJ} \mathrm{~mol}^{-1}$ and $18.80 \mathrm{~kJ} \mathrm{~mol}^{-1}$ which is in different solvent, it can be concluded that, in ionic liquid/water mixture, the activation energy of $s-p \mathrm{sc}_{4}$ are much lower then in other solvents. Guowang Diao reported that, the diffusion of calixarene in organic solvent is much easier then in aqueous solution ${ }^{6}$, however, the study in ionic liquid/water mixture show that it is much difficult to diffuse in ionic liquid due to the viscosity of the ionic liquid although in the presence of water .

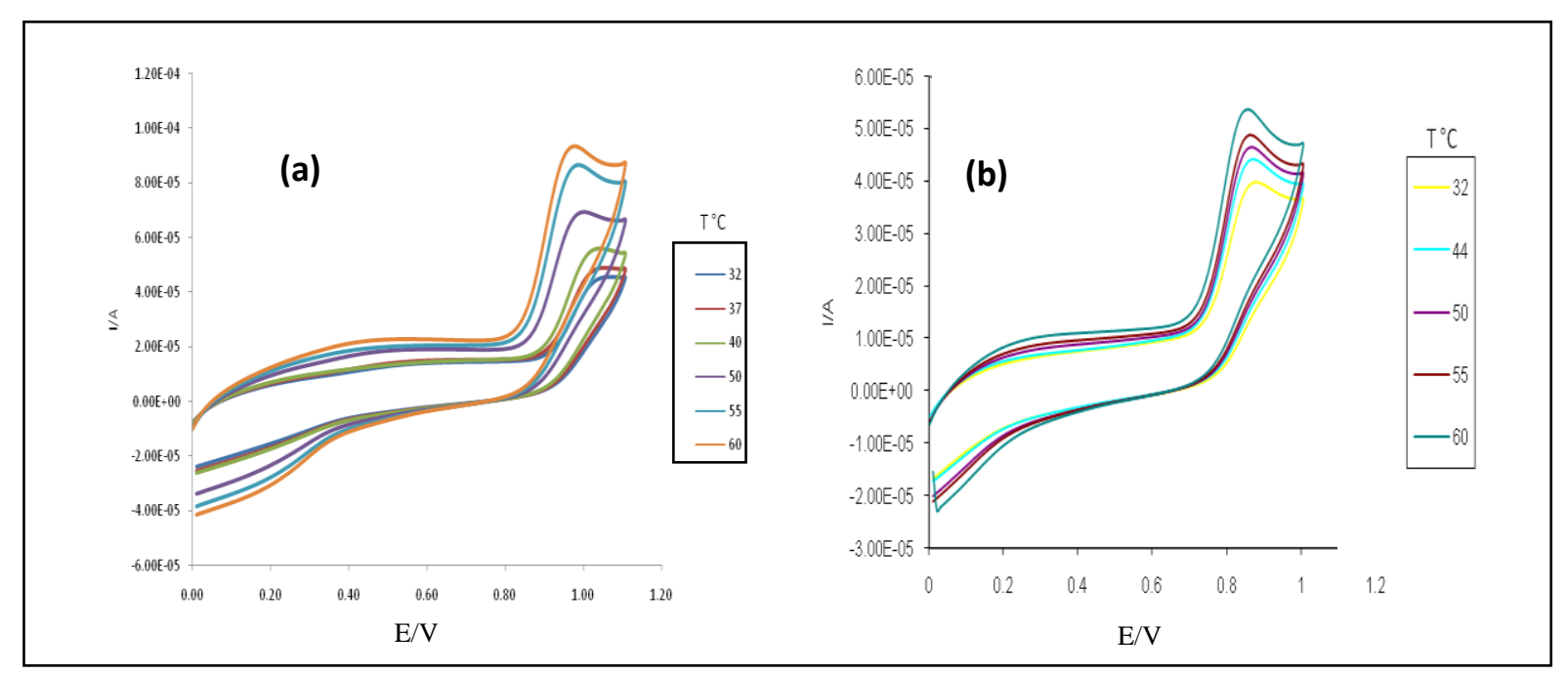

Figure 5 Cyclic voltammograms of $s-p \mathrm{sc}_{4}$ in (a) $0.12 \mathrm{M}[\mathrm{BMIM}]\left[\mathrm{BF}_{4}\right] /$ water mixture (b) $0.12 \mathrm{M}$ [BMIM][OTf]/water mixture up to $60^{\circ} \mathrm{C}, 100 \mathrm{mV} / \mathrm{s}, \mathrm{GC}$ versus $\mathrm{SCE}$. 


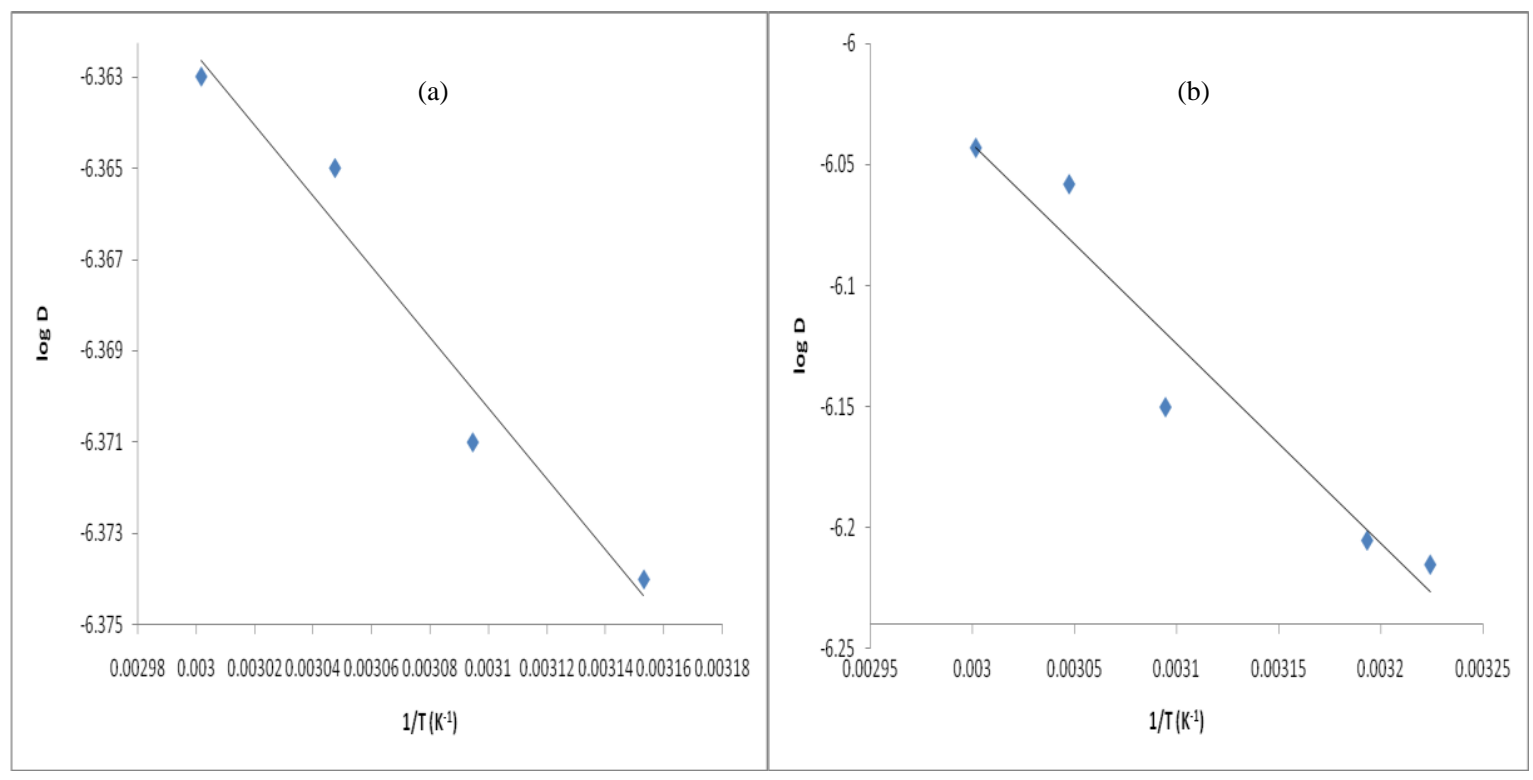

Figure 6: Plot $\log D$ versus $1 / T\left(\mathrm{~K}^{-1}\right)$ (a) $0.12 \mathrm{M}[\mathrm{BMIM}]\left[\mathrm{BF}_{4}\right] /$ water mixture (b) $0.12 \mathrm{M}$ $[\mathrm{BMIM}][\mathrm{OTf}] /$ water mixture $0.12 \mathrm{M} \mathrm{s}-\mathrm{psc}_{4}$ in [BMIM][OTf]/water mixture

\section{CONCLUSION}

The electrochemistry of $p$-sulfonatocalix[4]arene in the presence of $[\mathrm{BMIM}]\left[\mathrm{BF}_{4}\right]$ or [BMIM][OTf] as supporting electrolyte shows similar behaviour as reported in aqueous solution $^{1,8}$ and/ or organic solvent ${ }^{2,6,9}$. The pathway of oxidation of sodium $p$ sulfonatocalix[4]arene have been discussed which proceed via a common one-electron intermediate of phenoxide. Temperature dependence study was carried out and activation energy for different systems are $18.18 \mathrm{~kJ} \mathrm{~mol}^{-1}$ and $18.78 \mathrm{~kJ} \mathrm{~mol}^{-1}$ respectively.

\section{ACKNOWLEDGEMENT}

We would like to thank University of Malaya for financial support from UMCiL research university grant TA009/2008A and TA009/2007A for supporting this work.

\section{REFERENCES}

1. Diao, G. W.; Liu, Y.; "The electrochemical behavior of $p$-sulfonated sodium salt of calix[6]arene.", Electroanalysis 2005, 17, 1279.

2. Diao, G. W.; Wei, Z.; "The electrochemical behavior of $p$-sulfonated calix[4]arene.", Journal of Electroanalytical Chemistry 2004, 567, 325.

3. Pailleret, A.; Magan-Oliva, N.; Ollivier, S.; Arrigan, D. W. M.; "Electrochemical oxidation of a tetraester calix[4]arene." Journal of Electroanalytical Chemistry 2001, $508,81$.

4. Pailleret, A.; Arrigan, D. W. M.; "Interfacial behavior of p-hexasulfonato-calix[6]arene at glassy carbon electrodes in alkaline aqueous solution studied by voltammetric methods.", Langmuir 2002, 18, 9447.

5. Steeman, E.; Temmerman, E.; Verbeek, F.; "Electrochemical Reduction Of Lanthanide Ions.2. 2nd Reduction Step Of Europium(Iii), Ytterbium(Iii) And Samarium(Iii) In Acidic Tetramethylammonium Perchlorate Solution.", Journal of Electroanalytical Chemistry 1978, 89, 113.

6. Pailleret, A.; Arrigan, D. W. M.; "Electrochemical oxidation of a tetraester calix[4]arene.", Electrochemistry Communications 2001, 3, 24.

7. Bartlett, P. N.; Tebbutt, P.; Tyrrell, C. H.; "Electrochemical Immobilization Of Enzymes.3. Immobilization Of GlucoseOxidase In Thin-Films Of Electrochemically Polymerized Phenols.", Analytical Chemistry 1992, 64, 138.

8. Fuller, J.; Carlin, R. T.; Osteryoung, R. A.; "The room temperature ionic liquid 1-ethyl3-methylimidazolium tetrafluoroborate: Electrochemical couples and physical properties." Journal of the Electrochemical Society 1997, 144, 3881.

9. Diao, G. W.; Gu, J.; "Electrochemical behavior of $p$-tert-butyl calix[8]arene in $\mathrm{CH}_{2} \mathrm{Cl}_{2}$.", Electrochimica Acta 2006, 52, 42. 
Malaysian Journal of Science 29 (2): 174-179 (2010) 